\title{
Management and control in Italian public companies
}

by Frank Wooldridge

The author considers recent law reforms which have impacted on management structures in Italian public companies.

\section{INTRODUCTION}

A major reform of Italian company law took place as the result of Decree law No 6 of January 17, 2003, which has had a considerable impact on management structures in the Italian public companies (societa per azioni). According to Article 2380 of the Civil Code (as amended by the latter Decree law) if the statutes of the company do not provide otherwise the administration and control of a public company is regulated by paragraphs 2,3 and 4 of section VI bis of Chapter $\mathrm{V}$ of the Code which relate to the management and control of public companies. The provisions of these paragraphs, which deal respectively with directors, the committee of auditors, and the audit of the accounts (controlle contabile) will be considered below.

However, Article 2380 also provides that the administration and control of the company may instead be governed by paragraphs 5 or 6 of section VI bis if the statutes of the company so stipulate. In such an event, significant functions given to the committee of auditors (collegio sindicale) of companies having a traditional structure are exercised instead when the dual board system is employed by the supervisory board; when the monistic system is used instead, certain such functions are performed by the internal audit committee (comitato per il controllo sulla gestione). By Article 2380(3), unless otherwise stipulated the rules concerning directors contained in paragraph 2 of section VI bis are applicable to the board of directors when the monistic system is used, and for the executive board when the dualistic system is used. These systems are governed by paragraphs 5 and 6 of section VI bis.

The choice given to Italian public companies by paragraphs 5 and 6 to make use of the new dualistic or monistic structures would seem to show the influence of German and English law, as well as of the European Company Regulation. When a company has a traditional structure the rules governing the committee of auditors differ according to whether or not the company is quoted.

Italian public companies which are listed on the Italian Stock Exchange have to comply with the guidelines contained in the Code of Corporate Governance, or explain why they do not do so. This Code emphasises the need for an adequate member of independent nonexecutive directors on the board of directors. Furthermore the board is required to set up an Internal Code Committee and a Remuneration Committee consisting mainly of independent directors.

\section{RULES APPLICABLE TO COMPANIES HAVING A TRADITIONAL STRUCTURE}

\section{Management}

The directors (amministratori) of a public company which adopts the above form may number one or more persons whose term of appointment may not exceed three years (Civil Code, Arts 2380 bis and 2383(2)). They are not required to be members of the company. The first directors are appointed by the deed of incorporation whilst subsequent directors are, in principle, appointed by the general meeting (Art 2383 (1), ibid). Persons who are under an interdict, or who are mentally ill or bankrupt, or who have been made subject to a penalty which results, even temporarily, in their interdiction from office are not eligible to be directors of a public company and, by Article 2382 of the Italian Civil Code, if they are so appointed, they forfeit office. The shareholders are empowered to reappoint a retiring director unless the statutes provide otherwise: they may also remove a director from office by a resolution of the general meeting, without prejudice to an action for damages if there is no just reason for such dismissal (Art 2383(3)).

The directors must appoint one of their number to be chairman (presidente) unless such an appointment has been made by the shareholders in general meeting (Art 2380 bis (4)). The chairman is entrusted with the tasks of presiding over general meetings and fixing the agenda of such meetings.

By Article 2388(1), the board of directors (consiglio di amministrazione) cannot deliberate validly unless a majority of its members are present. The statutes may provide for an enhanced majority. Provided that the statutes so stipulate, or the general meeting so consents, the board of directors may delegate powers to the one or more of its 
members (directtore general or comitato esecutivo), except in relation to the preparation of the accounts, the issue of bonds, the increase of a company's capital, the reduction of the company's capital because of losses, and the requirement of calling a general meeting because of the loss of more than one third thereof (Arts 2381, 2423, 2420 ter, 2443, 2446 and 2447).

This limitation also exists in relation to the directors' powers in relation to the preparation of a merger proposal or one for a division (Arts 2501 ter and 2506 bis). The board of directors determines the contents, limits and modes of exercise of the delegated powers, and may always issue instructions to the relevant organ (executive committee or managing director); it is also empowered to perform the delegated functions itself. Furthermore the board is also empowered to evaluate the general development of the business of the company on the basis of reports from its subsidiary organs, i.e. the executive committee or managing director (directore general). The later individual is often the same person as the chairman.

According to Article 2384 of the Civil Code, the power of representation granted to the directors by the statutes or of the resolution appointing them is a general one. Limitations of the powers of the directors contained in the statutes or in a company resolution are not opposable to third parties, even if they are published, unless it can be shown that the third party has acted with the intention of harming the company. The provisions of Article 2384 would seem to conform with the requirements of the First Company Law Directive, and to be similar to those of German law (see paras 31 and 164 of the German Civil Code).

The remuneration of members of the board of directors or the executive committee is determined by the statutes or by the general meeting. It may take the form of a salary, or a share in the profits. The remuneration of the directors who are entrusted with specific tasks is determined by the board of directors in consultation with the committee of auditors (Art 2389). Particulars of the amount of remuneration received by the directors and auditors must appear in the notes to the accounts (nota integrativa), and be given on a cumulative basis for each category (Art 2427, cl 16). Directors and auditors of listed companies must declare annually to the National Commission for Companies and the Stock Exchange (Commissione Nazionale per la Società e la Borsa - CONSOB) the total amount of remuneration of any kind whatsoever obtained from the company or its subsidiaries (Law no 216 of 7 June 1974, Art 17).

According to Article 2392 of the Civil Code, directors must fulfil the duties imposed on them by law and the statutes with the diligence required by reason of their office and by their specific competence. They are jointly and severally liable to the company for damage resulting from their failure to respect this requirement, unless the relevant tasks come within the competence of the executive committee or one or more particular directors. Furthermore, the directors are also jointly and severally liable when they become aware of prejudicial acts and do not do all within their power to prevent their performance and eliminate or diminish their harmful consequences. Nevertheless, a director who is himself without fault may avoid liability for an improper transaction resolved on by the board by recording his dissent in the minutes of the meeting, and giving written notice to the chairman of the committee of auditors. It follows from Article 2380(3) that the same rules are applicable to the members of the executive board and the board of directors (consiglio di amministrazione) when the new dual board or monistic system of management is used.

By Article 2390, a director may not participate in the management of a business which competes with that of the company, nor be a general partner in a competing firm, unless he is authorised to by general meeting. Failure to comply with these prohibitions may be sanctioned by dismissal from office, and result in liability for damages.

The provisions of Article 2391 are designed to further transparency and are applicable in the absence of any actual conflict of interest. Article 2391(1) provides that should a director be interested either on his own account, or on behalf of a third party, in a particular company transaction, he must disclose prescribed details of that interest to his fellow directors and the committee of auditors. If he is empowered to conclude the transaction, he must abstain from doing so, and refer the matter to the board. The latter body must give adequate reasons for approving the transaction (Art 2391(2)). If the above provisions are not complied with, and if the board or executive committee's decision is adopted by reason of the vote of the interested director and is liable to cause harm to the company, the directors or the committee or auditors may challenge the decision within 90 days of its adoption. However directors who voted for the latter decision cannot challenge it, but absent or dissenting ones can. In all cases, the rights of third parties acting in good faith on the basis of the decision are protected (Art 2391(3)).

The directors are responsible for the damages suffered by company as the result of their acts or omissions (Art 2391(4)). Furthermore, Article 2391(5) provides that directors are liable to the company for damages suffered by it by reason of the utilisation for their own advantage or for that of third parties of facts, information or opportunities about which they have become acquainted in the course of their duties. The latter rule reminds one of the corporate opportunity rule which is recognised under English and American law.

An action for breach of the duties of the directors duties may be brought by the company, even if it is in liquidation, if the shareholders in general meeting so resolve, and the resolution is passed by the favourable votes of the holders 
of at least one-fifth of the company's share capital (Art 2392(1) and (4)). The action must be brought within five years of the termination of the relevant directors' office (Art 2393(3)). The passing of such a resolution means that the relevant director is automatically dismissed. However, the company may waive the brining of such an action or compromise it if such procedure is not opposed by the holders of at least one-fifth of the share capital. This fraction is reduced to one-twentieth, or the lesser amount permitted by the statutes, where the company has recourse to the market for venture capital, ie it is a listed company, or has more than 200 members (Art 2393(5)). Individual shareholders holding at least one-fifth of the share capital, (which amount may be increased up to one-third) may bring a derivative action against the company. This fraction is reduced to one twentieth or the lesser amount permitted by the statutes, in the case of companies which have recourse to the market for venture capital (Art 2393 bis (1) and (2)). Creditors may bring an action against directors who have not complied with the legal obligations concerning the preservation of the company's assets (Art 2394). A personal action may also be brought by members who have suffered loss as the result of the fraud or negligence of the directors (Art 2395).

Similar rules to those discussed above were made applicable by Article 129 of Decree Law No 58 and 1998 to derivative actions against directors, managing directors, and members of the committee of auditors of an Italian companies quoted on a regulated market in Italy, or in another EC state. Such an action might be brought by persons who have been entered in the company's register of shareholders for at least six months, and who held at least 5 per cent of the company's capital, or such lesser percentage as was prescribed by the statutes. The requirement of minimum holding time has been abolished. However, because of the absence of rules governing class actions or permitting contingency fees, derivative actions are unlikely to become common in Italy.

\section{COMMITTEE OF AUDITORS}

\section{Position in unlisted companies}

The rules governing the functions of the above entity differ considerably according to whether or not the company is a listed company, and as fully explained below, whether the traditional rules governing management are adopted, or whether the new dualistic or monistic system described below is adopted, when the supervisory board or the internal audit committee (comitato per il controllo sulla gestione) is entrusted with certain functions similar to those of the committee of auditors in traditional companies.

The rules governing the committee of auditors of unlisted companies are principally contained in Articles 2397-2409 of the Civil Code, and have undergone a number of revisions in recent years, culminating with the enactment of the new provisions of the Civil Code in 2003.
The committee of auditors of an unlisted company consists of between three and five persons, who may or may not be members. In addition, two alternative auditors must be appointed. At least one of the auditors and a substitute must be entered on the register of auditors maintained by the Ministry of Justice. The rest of them must be entered on a prescribed professional register, or be established university teachers (Art 2397). The auditors are appointed for a period of three years by the general meeting, and, in the case of the first auditors, by the deed of incorporation (Art 2400). Article 2399 contains elaborate rules according to which certain persons are ineligible for appointment to the committee of auditors of an unlisted company, or are required to vacate office, if so appointed. Similar rules are made applicable to listed companies under the provisions of Article 148(3) of Decree Law No 58 and 1998. The removal of, or the suspension of an auditor from the official register of company auditors, results in his loss of membership of the committee of auditors.

Although the committee of auditors has important controlling functions, these do not extend to the audit of the accounts except in the case of a company which does not have recourse to the market for venture capital, and which is not required to prepare consolidated accounts (Art 2409 bis (3)). In the latter case, the committee will be made up of auditors contained in a list approved by the Ministry of Justice. The accounts of a company which has recourse to the market for venture capital must be audited by a properly qualified auditing firm supervised by CONSOB, and regulated by certain special rules. Detailed rules concerning the audit of the accounts of a company adopting the traditional rules governing management and control are contained in Articles 2409 bis to 2409 septies of the Civil Code. In the case of companies employing the new dualistic structure, the audit of the accounts is governed by Articles 2409 quinquiesdecies and 2409 noviesdecies (2), which are in very similar terms, and which make reference to the abovementioned provisions of the Civil Code.

The committee of auditors of an unlisted company must report to the general meeting on the balance sheet. The position is similar in listed companies (see Civil Code, Articles 2429 (2) and Decree Law No 58 of 1998, Art 153(1)).

The members of the committee of auditors must attend board and general meetings, and meetings of the executive committee of the board of directors (Art 2405(1)). They are also required to satisfy themselves that the law and the statutes and the principles of correct administration have been observed and that the organisational, administrative and accounting arrangements adopted by the company are adequate, and on their practical functioning (Art 2403). The auditors are empowered to carry out acts of inspection and control at any time on an individual basis (Art 2403 bis (1)). They may make use of their own 
employees for this purpose, unless such persons are disqualified under Article 2399 of the Civil Code (Art 2403 bis (4)). They are required to carry on an investigation into alleged wrongdoings without delay if asked to do so by the holders of one-twentieth of the company's share capital (Art 2408(2)). A similar rule is contained in Article 128(1) of Decree Law No 58 of 1998, which is applicable to listed companies. The required fraction of the company's share capital is reduced to one-fiftieth in the case of companies which have recourse to the market for venture capital; this rule is also applicable to listed companies.

According to Article 2409(1), the holders of one-tenth of the company's capital (one-fiftieth in the case of companies having recourse to the market for venture capital) may make a report to the competent tribunal if there is justified suspicion of grave irregularities in the fulfilment of the duties of the directors or the auditors which cause damage to the company or to one or more companies controlled by it. The tribunal may order an investigation into the management of the company at the cost of its shareholders (Art 2409(2)). It will not act in this way, and will adjourn the proceedings for a specific period if the general meeting replaces the directors and auditors with persons of adequate professional competence, who must determine without delay whether irregularities have taken place, and should they find that they have, make reference to the tribunal on the results of the investigation, and on the actions taken (Art 2409(3)). Should such procedures prove insufficient to eliminate the irregularities, the tribunal may order provisional measures and call a general meeting for the purpose of passing the necessary resolutions. In the most serious cases, it may remove the company's directors and auditors from office and order the appointment of a judicial administrator, who will be charged with the temporary management of the business (Art 2409(4)).

According to Article 2409(5), action may be taken under Article 2409 by the supervisory board or internal audit committee as well as by the committee of auditors. Where the company has recourse to the market for venture capital, it may also be taken to the Public Prosecutor.

\section{The position in listed companies}

It seems appropriate to deal with this matter here, although the role of the committee of auditors of such companies will be of less significance when they do not adopt the traditional system of management. Many of the rules governing the committee of auditors of a listed company are contained in Articles 148-154 of Decree Law No 58 of 24 February 1998. Certain of the rules contained in the Civil Code are disapplied as far as auditors of listed companies, ie Italian companies which are listed on an Italian regulated market or on one in another member state of the EC are concerned. The provisions which are disapplied by Article 154 of Decree Law No 58 and 1998 are Articles 2397-2399, 2403, 2403 bis, 2405(1), 2426 sentences 5 and 6, 2429(2), 2435 bis 2440 and 2441(6). It follows that the rules governing the appointment of members of the committee of auditors contained in Article 2401; those governing their remuneration contained in Article 2402; those governing meetings and resolutions contained in Article 2404; those concerning the giving of notice of general meetings by auditors if directors fail to do so contained in Article 2406; those governing the liabilities of auditors contained in Article 2407; and those governing reports to the committee of auditors and the court contained in Articles 2408 and 2409 are applicable to the committee of auditors of listed companies.

According to Article 148(1) or Decree Law No 58 of 1998 the statutes of listed companies must state the number of regular members of the committee of auditors, which must not be less than three, and the number of alternate members, which must not be less than two. They must also state the method of, and requirements for, nomination as chairman of the committee, and the limitations on the number of offices which may be held by the members thereof. Article 148(2) provides that the statutes must contain provisions ensuring that the minority shareholders must elect at least one member of the committee. If this has more than three members, the required number is instead two. Detailed provisions concerning ineligibility for appointment as auditors of listed companies are contained in Article 148(3), which also applies to persons who are disqualified from holding office as a director under Article 2382 of the Civil Code. It applies to spouses, parents, parents-in-law of, and persons within the fourth degree of relationship to directors on the company; or any company which controls it or any subsidiaries; as well as to senior and other employees of the company or any company which controls it, or any subsidiaries. The professional qualifications and conduct of members of the committee or auditors has been the subject of decrees made by the Ministry of Justice.

The duties of the committee of auditors of a listed company are set out in Article 149(1) of Decree Law No 58 of 1998 . It is thus required to examine whether the law and statutes of the company are observed, and whether the principles of correct administration are adhered to. It must also examine the adequacy of the organisation of the company, particularly from the viewpoint of the allocation of competences, the system of internal control and that of management accounting, as well as the suitability of that accounting system for the purpose of representing management transactions. The committee of auditors is also required to examine the adequacy of the provisions made by a controlling company for the purpose of ensuring that a subsidiary has given the notices to it which are required by law.

Article 149(2) of the Decree Law of 1998 requires the members of the committee of auditors to assist at general meetings and meetings of the board of directors and of the executive board. By Article 149(3) the committee of 
auditors is required to communicate to CONSOB without delay any irregularity it finds in exercising its supervisory tasks, and to send it the relevant minutes of the particular meeting and of the investigations undertaken, together with any other useful documentation. Paragraph 3 does not apply to Italian companies which are only listed on a regulated market in another EC state.

The directors are required by Article 150(1) of Decree Law No 58 to report to the committee of auditors in good time, and in accordance with the requirements of the deed of incorporation, and at least on a three monthly basis on activities which have been carried out, and on operations of major economic, financial or patrimonial importance affected by the company, or by a company controlled by it, and in particular on operations which involve a potential conflict of interests.

Article 151 of Decree Law No 58 of 1998 sets out the powers of the committee of auditors. Paragraph 1 of this provision provides that the auditors have the power, acting individually or otherwise, to ask the directors to notify them of the progress of company operations or of a determinate matter, as well as to proceed at any time to measures of inspection and control. By Article 151(2) the committee of auditors may, on giving notice to the chairman of the company, call a general meeting, a meeting of the board of directors or of the executive board, and may call on employees of the company to assist them in performing their tasks. Similar powers may be exercised by two members of the committee.

According to Article 151(3) the committee of auditors may, for the purpose of determining the adequacy of and appropriateness of the system of management accounting make use of its own employees at its own responsibility on an individual or other basis, and at its own expense provided that such employees are not disqualified from acting under Article 148(3) of Decree Law No 58 of 1998. Furthermore, Article 151(4) provides that the auditors are responsible for recording the investigations made by them in the register of deliberations and meetings of the committee kept at the company's head office.

According to Article 152(1) and (2) of Decree Law No 58 of 1998, if they have justified suspicion of grave irregularities in the fulfilment of the duties of the directors, the committee of auditors or CONSOB may report the matter to the competent tribunal under Article 2409 of the Civil Code. The costs of the investigation must be borne by the company. The court is empowered to dismiss individual directors when the committee of auditors has reported to it. CONSOB may, according to Article 152(3), not make a report to the court where the relevant Italian company's shares are listed only on a regulated market in another EC state.

It may be noted that Article 152 of the Decree Law No 58 at 1998 contains somewhat similar but less detailed provisions to those of Article 2409 of the Civil Code.
Finally, Article 153(1) of Decree Law No 58 of 1998 provides that the committee of auditors reports to the general meeting convened for the purpose of approving the accounts on the supervisory activities it has undertaken, and the blameworthy acts revealed. In addition, Article 153(2) provides that the committee may make proposals to the general meeting concerning the accounts and their approval as well as on other matters within its competence.

\section{THE DUAL BOARD SYSTEM}

Under the above system, the supervisory board has some of the powers which, under the traditional system, are entrusted to the general meeting, for example the appointment and dismissal of the members of the executive board (which corresponds to the board of directors) and many of those which are entrusted to the committee of auditors when the traditional system, which has been described above, is used. These include the supervisory tasks which are given to the latter committee under Article 2403 when the latter system is used. It is given other powers which would belong to the committee of auditors under the traditional system of management and control by Article 2409 quaterdecies.

The powers of the supervisory board are set out principally in Article 2409 terdecies of the civil Code. Under the dual board system, the board is responsible (as in Germany) for the approval of the accounts (Article 2409 terdecies (b)). As already indicated under all three systems of management, the accounts also have to be approved by external auditors. The only exception to this rule applies to public companies which do not have recourse to the market for venture capital, and which do not have to produce a consolidated balance sheet. As already indicated the statutes of such companies may entrust the committee of auditors with auditing functions, provided that they are suitably qualified. Article 2409 terdecies (d) empowers the supervisory board to bring actions against member of the executive board who have been responsible for breaches of their duties. The supervisory board is empowered by Article 2409 terdecies (e) to make a report to the competent court in accordance with Article 2409, which has been discussed above. Finally, by Article 2409 terdecies (f), the supervisory board is required to report at least once a year to the general meeting on the performance of its supervisory tasks, and on blameworthy matters discovered by it.

The members of the supervisory board are required to perform their tasks with the degree of diligence required by reason of their office. They are jointly and severally liable together with the members of the executive board for the latter's acts or omissions which result in damage which would not have occurred had they exercised the degree of supervision appropriate to their office.

The supervisory board must consist of at least three members. The original members must, according to Article 
2409 duodecies (2) and (3) be appointed in the deed of incorporation, whilst later appointments, which are for a maximum period of three years, are made by the general meeting. According to Article 2409 novies, the members of the first executive board are appointed by the deed of incorporation: subsequent appointments are made by the supervisory board. The maximum period for appointments is three years. The task of the executive board is to carry out the tasks necessary for the purpose of attaining the company's objects. It must consist of at least two members, who need not be shareholders. Article 2409 novies (4) makes it clear that members of the executive board may not be appointed to the supervisory board. A number of rules which are applicable to the board of directors of a traditional company are made applicable to the executive board by Article 2409 undecies.

\section{THE UNITARY BOARD SYSTEM}

This model involves a board of directors (consiglio di amministrazione) which is responsible for management of the company and a committee of such a board (comitato per il controllo sulla gestione) the internal audit committee which is appointed by the directors unless the statutes provide otherwise (Arts 2409 septiesdecies and octiesdecies). The members of this committee do not participate in the management of the company. One third of the members of the board must fulfil the requirements of independence imposed on members of the committee of auditors. If the statutes so provide, such persons may also be required to conform with the codes of conduct of professional bodies, or with those applicable to management companies of regulated markets.

Unless the statutes provide otherwise, the members of the internal audit committee are appointed by the board of directors. In the case of companies which have recourse to the market for venture capital, the requisite number of members is three. The members of the committee must comply with the requirements of integrity and professionalism stipulated in the statutes and with those of independence stipulated for members of the committee of auditors in Article 2399. They must not exercise management functions in the company itself or one which controls it, or in one which it controls (Art 2409 octiesdecies (2)). At least one member of the internal audit committee must be entered on the register of auditors (revisori contabili).

The functions of the committee are set out in Article 2409 octiedecies(5). It examines the adequacy of the organisational structure of the company, and its system of internal control, administration and accounting, particularly whether this system is suitable for the purpose of correctly representing the management of the business. Furthermore it examines the performance of other duties entrusted to the directors, and in particular their relationship with those responsible for the audit of the account. Certain of the rules made applicable to the committee of auditors under the traditional system, ie those in Articles 2404(1), (3) and (4), 2405(1), 2408 and 2409 are also made applicable to the internal audit committee. The provisions of Article 2404 relate to meetings and resolutions; and those of 2405(1) to participation in the meetings of the board of direcrors and the general meeting. Article 2408 relats to reporting blameworthy facts to the committee of auditors, whilst Article 2409 relates to invoking the jurisdiction of the court.

Most of the provisions relating to the board of directors of a company adopting the traditional rules relating to management and control are made applicable to the board of a company set adopting the new monistic system by Article 2409 noviesdecies(1). The audit of the accounts of such companies is regulated by the rules set out in Article 2409 noviesdecies(2).

\section{CONCLUDING REMARKS}

The above provisions of Italian law are very detailed, and perhaps made a little difficult to understand because of the fact that although the reform of January 22, 2003 was far reaching, it did not attempt to consolidate all the relevant provisions of Italian company law. It remains to be seen what use will be made in practice of the two new models, which are likely to serve rather different needs. It may be that the dualistic model will remain fairly uncommon as it still apparently is in France. However, the powers of the supervisory board to bring an action against defaulting directors may have some tendency to render the latter model attractive to some (note in this sense D Santosuosso, Il nuovo diritto societario, pub D\&G 2003, p 72). One may question whether the separation of functions between the members of the board of directors who are concerned with management and the internal audit committee of that board under the new monistic system will always work effectively in practice.

Frank Wooldridge

Formerly Adjunct Professor, University of Notre Dame. 